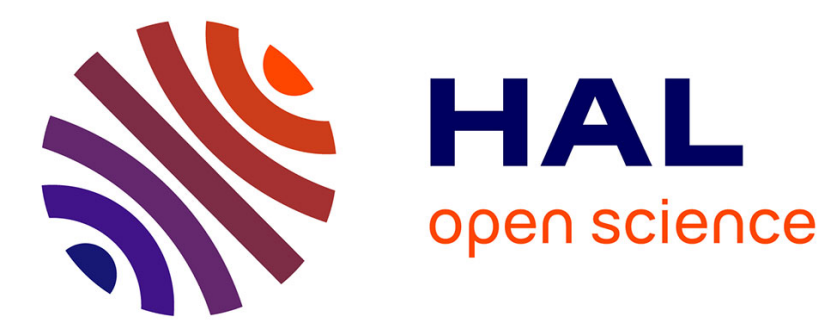

\title{
Thoughts about responsibility in anthropological research, from a study with the Baka Pygmies
}

\author{
Fernando Ramirez Rozzi
}

\section{To cite this version:}

Fernando Ramirez Rozzi. Thoughts about responsibility in anthropological research, from a study with the Baka Pygmies. Ethics, Medicine and Public Health, 2021, 18, pp.100668. 10.1016/j.jemep.2021.100668 . hal-03356189

\section{HAL Id: hal-03356189 \\ https://hal.science/hal-03356189}

Submitted on 28 Sep 2021

HAL is a multi-disciplinary open access archive for the deposit and dissemination of scientific research documents, whether they are published or not. The documents may come from teaching and research institutions in France or abroad, or from public or private research centers.
L'archive ouverte pluridisciplinaire HAL, est destinée au dépôt et à la diffusion de documents scientifiques de niveau recherche, publiés ou non, émanant des établissements d'enseignement et de recherche français ou étrangers, des laboratoires publics ou privés. 


\title{
Thoughts about responsibility in anthropological research, from a study with the Baka Pygmies
}

\author{
F. Ramirez Rozzia,b,*
}

\author{
a UMR 7206 écoanthropologie, musée de l'homme, MNHN, CNRS, UP, 17, place du Trocadéro, 75016 Paris, France \\ b URP 2496 orofacial pathologies, imaging and biotherapies, UP, Montrouge, France
}

Received 29 March 2021; accepted 5 April 2021

\section{Summary}

Backgrounds. - Constraints on studies of present-day populations have been increasing over the past 20 years. Looking beyond whether or not each type of constraint is justified, the effect is to raise a barrier which is primarily a response to theoretical questions from people who seem to have very limited experience on the ground and who know even less about the expectations of the populations they propose to 'protect'.

Methodology. - For fifteen years, I have been regularly and systematically monitoring a pop- ulation of Baka pygmies in southeastern Cameroon to study their somatic growth and life history.

Discussion. - The warmth of the Baka people's welcome to researchers, their curiosity about 'other worlds' and their interest in the subjects addressed by the scientists who visit them stand in sharp contrast with the numerous and constraining restrictions placed upon those who want to go there for scientific projects in which the Baka themselves are interested and actively participating. The divorce between the interests of the Baka and the provisions of international protocols necessarily raises questions about the foundations on which certain organizations manage contacts and, to a certain extent, determine the 'life' of indigenous peoples, since the latter, with very few exceptions, are absent from the committees which have to decide on research projects that involve them.

Conclusion. - It is essential for groups concerned by a research project to be consulted and if a committee has to assess the research project, members of the group concerned must be invited to participate in it. This would not add further delay to these already excessively long and expensive procedures. Above all, it would give the groups concerned full sovereignty over research projects concerning them.

\footnotetext{
This article has been presented as a paper at the international congress « Anthropo-responsibility (musée du quai Branly - Jacques Chirac, Paris, France), January 28-29th 2021.

*Corresponding author at: UMR 7206 écoanthropologie, musée del'homme, MNHN, CNRS, UP, 17, place duTrocadéro, 75016 Paris, France.

E-mail addresses: fernando.ramirez-rozzi@mnhn.fr, fernando.ramirez-rozzi@mnhn.fr
}

https://doi.org/10.1016/j.jemep.2021.100668

\section{Introduction}

After working on somatic growth (ontogenesis) during human evolution and observing the diversity of growth patterns among fossil hominin species, my study projects have focused on the diversity of these patterns among modern human populations. I approached this subject in 2007 and began a study on the somatic growth and life history of a population of Baka pygmies in south-eastern Cameroon. The results have already been the subject of several publications [1-13].

This research was carried out under international coop- eration arrangements and as the years went by, each project had to be approved by new and different committees assess- ing whether they meet the ever more numerous new and binding standards imposed on researchers by international bodies. New project offices have thus appeared in different research organizations to help researchers set up projects that take into account the new constraints being imposed to supposedly ensure better respect for the Other and the environment.

Notwithstanding international agreements and accep- tance of a project by multiple committees in the countries concerned (those of the researchers and the country where the research takes place), the real challenge for carrying out a research project in any particular field lies in securing the acceptance and involvement of the community where the research will be carried out. A research project will only be successful if the community has a vested interest in the study and is concerned by it, which will result in close collaboration with the research team. The following is a simple anecdote about how I was allowed to pursue my research project among the Baka, which shows where the truth of field research lies: 
the rest is just fiction to salve the conscience of deskbound technocrats.

\section{Among the Baka}

On the morning of my first day of my first stay with the Baka, I was put to the test and the future of my research project was clearly at stake. As I walked in the company of two Baka, who over the years would become not only my senior collaborators but also dear friends, we heard increasingly high voices in the Baka language. As we moved forward, the voices became louder and louder and the phrases in Baka

alternated with sentences in French, which meant that these vociferations concerned me. We were approaching Chief Baka's neighbourhood in the community of Le Bosquet. I was able to establish at that moment that the shouting came from the discussions hut (case à palabres) in the chief's quar- ters, in which were gathered the chief, his adult children and some village elders. They were staring in my direc- tion while saying sentences in French that were increasingly identifiable. It was clear that their words were directed at me. "What's that white person doing here?" "Who allowed him to come?" "Why is he walking around here?" Not very welcoming sentences, and accompanied by suspicious looks and some hostile grimaces. I walked straight towards them. Within a few minutes, I was standing in front of the dis- cussion hut, alone, without my Baka collaborators who had disappeared into the surrounding forest. As I stood in front of the chief and the others, they questioned me in an admoni- tory way about my presence at Le Bosquet. I spoke frankly. "As you know”, I told them, "you are smaller than any other people, and so we, white people, want to know why." I asked them for permission to come to Le Bosquet and to measure people. Their immediate response was "What is the benefit for us?" I told them that thanks to my work we would be able to build a growth curve for them, so that in the future, when doctors came, they would be able to check their growth individually and see if any children were mov- ing away from that curve, which would mean they were not growing well. "If doctors don't use this curve', I added, "they will use one that has been established for different people and they will say that you are all sick with growth problems because of course you are smaller and you do not grow like others." They understood perfectly, but they immediately added, "And what else, what other benefit?', Since I was also going to study dental development, I sug- gested that I could bring them a dentist from time to time to provide free dental care for the Baka, with my research covering all expenses (Fig. 1). They agreed right away and allowed me to stay and do my job. I explained that I would come for several years in a row, which made them even more favourable to my work because “We don't like peo- ple who come once, and afterwards they are never seen or heard again, they don't care about us, they take what they are looking for and leave without showing any consideration for the Baka people'", they explained. I reassured them that this was not my case since they would have to put up with me for many years. I bowed to the chief and took leave of him and the others. In just a few minutes, I had passed the fundamental test for the pursuit of my research project.

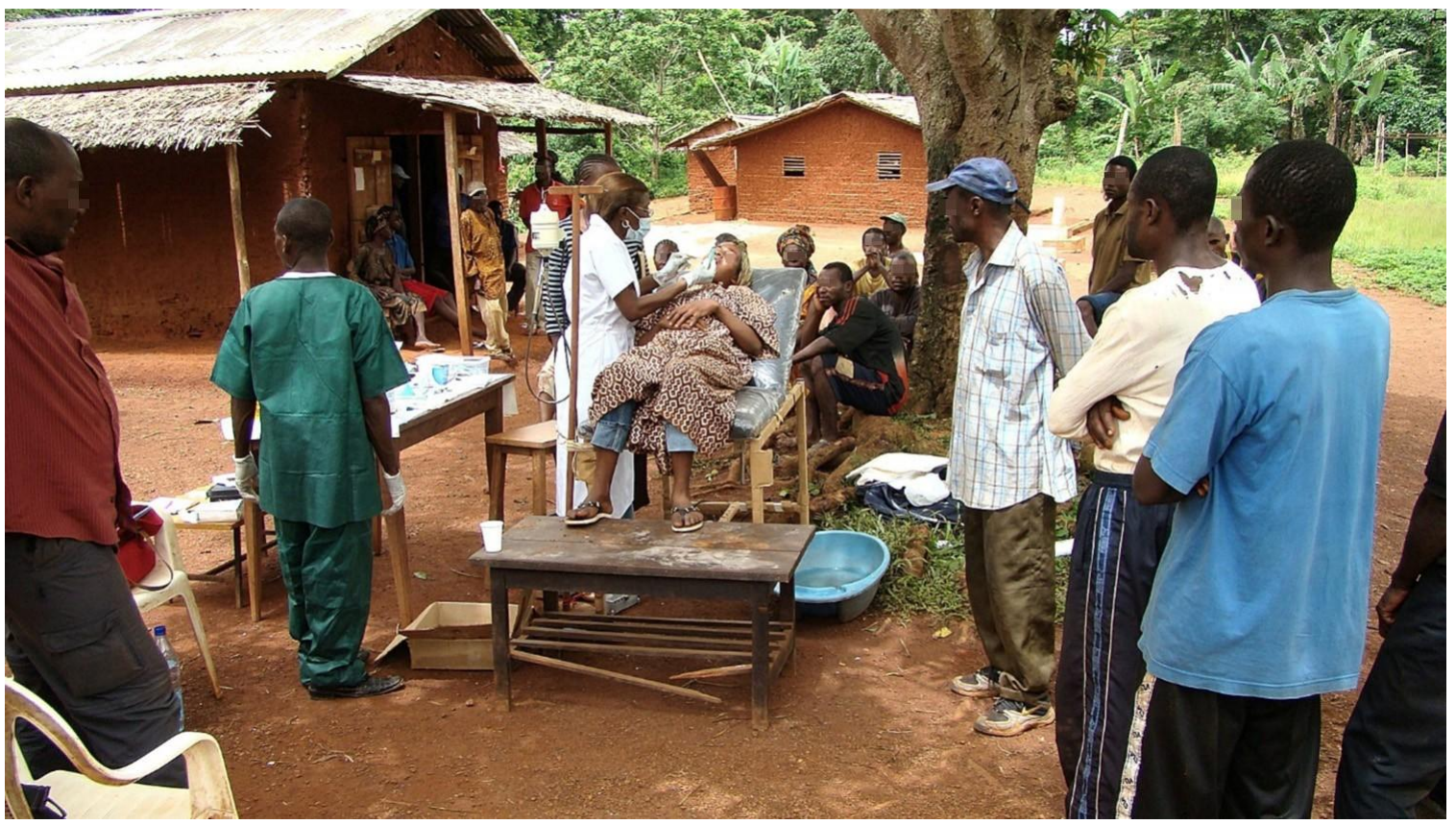

Figure 1. A mobile dental surgery set up so that dental care can be provided in the middle of the African bush without a water and electricity supply. After treating the Baka at Le Bosquet, the Cameroonian dentist (white coat) went to Messéa, a village of the Nzimé people (Bantu group). The dental nurse (green coat) accompanying the dentist is a Baka, which produces a rather special situation in this environment because it must be remembered that in Bantu-Baka relations, the Baka tend to be considered by the Bantu as 'sub-human' or as 'talking chimpanzees'. The Baka constantly ask us to take pictures of them and especially with them. Some Westerners might see some of these photos as 'colonial' images 
and criticise them as such. Should we refuse to take this type of photo? Why deny people a memory they can only obtain in our presence because they have no cameras and their phones can only be charged from time to time and randomly? Should we deprive the Baka of these images on the pretext that they convey ideas that have no resonance for them? Should concepts or ideas established in the West by Westerners prevail over their desires? Who wants to impose ideas forged in the West on these people, on the pretext of protecting their freedom but which ultimately amounts to another kind of imposition? Not me.

\section{Research done with the Baka}

From 2007 to 2019, I was able to carry out many research projects thanks to the collaboration of the Baka at Le Bosquet. My long stays with them and my commitments kept over many years made it possible to establish a close relationship based on mutual respect, a sense of shared con- cerns and real affection. It is a pleasure to present the results already obtained to them and to be asked about the next aspects to be addressed in further research concerning them. They ask for many analyses themselves and become indignant when we explain to them that we cannot carry out many of the analyses that they ask for because we have to ask for the agreement of committees that oppose them because they "only" concern fundamental research. Obvi- ously their anger is accompanied by comments such as "Why do others decide for us?"

\section{Decisions made without the Baka}

Applications for permits (because this is what they are) to conduct research in a group (ethnic group/community/people) must go through an assess- ment by committees in which, in most cases, the groups concerned by the research are not represented, let alone consulted. These committees, whose members will judge whether the research protocols comply with national and

especially international rules, are guided by thinking built up in contexts that are often very distant from the reality of the field where the research will be carried out. To return to the specific case of the Baka, although the Baka themselves are asking for studies that include invasive and non-invasive analyses (blood, X-rays, tissue, intestinal biota, etc.), the members of the committees refuse such requests on the basis of criteria dictated by national or international bodies. There is no link between the decisions on the research that can be done and the wishes of the groups concerned. In other words, one group of 'well-informed' people decides for another group which is, ultimately, judged to be incapable of deciding for their own good. Does this split relationship between decision-makers and protagonists not imply a kind of paternalism? Is there not behind this approach a vision of superiority of the one over the other? Are we not facing a form of 21 st century neo-colonialism?

In addition, the filtering function of these committees seems to mean that their members think that the researcher can impose his will on a group which in turn is considered unable to defend itself and refuse it. Do the members of these committees think that the researcher can carry out his work without the consent of the group? Do they think that the researcher has forced or will force individuals to participate? Do they think that the researcher has the means to do so?

All of this ultimately reflects an unpleasant distrust of researchers, a notable disregard for the ability of groups to decide in their own interests and, above all, all it reveals a profound lack of knowledge of field work.

\section{Conclusion}

It is essential for groups concerned by a research project to be consulted and if a committee has to assess the research project, members of the group concerned must be invited to participate in it. This would not add further delay to these already excessively long and expensive procedures. Above all, it would give the groups concerned full sovereignty over research projects concerning them.

\section{Human and animal rights}

The authors declare that the work described has not involved experimentation on humans or animals.

\section{Informed consent and patient details}

The authors declare that the work described does not involve patients or volunteers.

\section{Funding}

This work did not receive any grant from funding agencies in the public, commercial, or not-for-profit sectors. 


\section{Author contributions}

All authors attest that they meet the current International Committee of Medical Journal Editors (ICMJE) criteria for Authorship.

\section{Acknowledgements}

I would thank the organization of the meeting 'Anthropo- responsabilité' to invite me to participate. I thank also the participants for the useful exchanges. The author thanks all the staff at the IRD in Yaounde for their logistical support and the nuns at the Le Bosquet mission for their kind hos- pitality. Special thanks to P. Kalo, J. B. Etoa and other Baka collaborators for their help, assistance and friendship dur- ing many years of work together. The original research was supported by the CNRS, the IRD and grants from the Wenner- Gren Foundation, National Geographic (\#8863-10) and ANR program Blanc 'GrowinAP'.

\section{Disclosure of interest}

The author declares that he has no competing interest.

\section{References}

[1] Correia AM, Foley R, O'Connell TC, Ramirez Rozzi FV, Lahr MM. Carbon and nitrogen isotopic signatures of hair, nail, and breath from tropical african populations. Rapid Commun in Mass Spec- trom 2019;33:1761-73.

[2] Pineau JC, Ramirez Rozzi FV. The same growth pattern from puberty suggests that modern human diversity results from changes during pre- pubertal development. Sci Rep 2021;11:4817, http://dx.doi.org/10.1038/s41598-021-84327-1.

[3] Ramírez Rozzi FV. Diversity in tooth eruption and life his- tory in humans: illustration from a Pygmy population. Sci Rep 2016;6:27405, http://dx.doi.org/10.1038/srep2740.

[4] Ramírez Rozzi FV. Reproduction in the Baka pyg- mies and drop in their fertility with the arrival of alcohol. Proc Natl Acad Sci USA 2018;115:E6126-34, http://dx.doi.org/10.1073/pnas.1719637115.

[5] Ramirez Rozzi FV. Intégration à deux vitesses d'un village pyg- mée Baka. In: Kulesza P, Robillard M, editors. Quel avenir pour les Pygmées à l'orée du XXlème siècle ? Paris: L'Harmattan; 2019. p. 137-42.

[6] Ramirez Rozzi FV. Chez les pygmies Baka de Cameroun. Voyage dans l'altérité. Paris: L'Harmattan; 2021.

[7] Ramírez Rozzi FV, Koudou Y, Froment A, Le Bouc Y, Botton J. Growth pattern from birth to adulthood in African pygmies of known age. Nat Commun 2015;6:7672, http://dx.doi.org/10.1038/ncomms8672.

[8] Ramírez Rozzi FV, Froment A, Ghesquière J. De l'est à l'ouest de l'Afrique, une seule morphologie pygmée qui diffère de celle des Non-pygmées. BMSAP 2018;30:90-101, http://dx.doi.org/10.3166/bmsap-2018-0009.

[9] Ramírez Rozzi FV, Romero A. Tooth dimensions and body size in a pygmy population. Ann Hum Biol 2019;46:467-76.

[10] Ramirez Rozzi FV, Sardi M. Diversity among African Pygmies. PLoS One 2010;5:e13620, http://dx.doi.org/10.1371/journal.pone.0013620.

[11] Romero A, Ramírez Rozzi FV, De Juan J, Pérez-Pérez A. Diet-related buccal dental microwear patterns in Cen- tral African Pygmy foragers and Bantu-speaking farmer and pastoralist populations. PLoS ONE 2013;8:e84804, http://dx.doi.org/10.1371/journal.pone.0084804.

[12] Romero A, Ramírez Rozzi FV, Pérez-Pérez A. Dental size vari- ability in Central African Pygmy hunter-gatherers and Bantu- speaking farmers. Am J Phys Anthropol 2018;166:671-81.

[13] Romero A, Ramírez Rozzi FV, Cuesta-Torralvo E, Perez-Perez A. Age-related tooth wear in African rainforest hunter-gatherers. Am J Phys Anthropol 2019;170:622-8. 